\title{
PERILAKU MASYARAKAT DALAM PENCEGAHAN DEMAM BERDARAH DI RT 03 RW 03 KELURAHAN TANGKERANG TENGAH KECAMATAN MARPOYAN DAMAI PEKANBARU
}

\author{
Isnaniar, Yendra \\ Prodi D III Keperawatan Universitas Muhammadiyah Riau \\ e-mail: isnaniar@umri.ac.id,yendra@studentumri.ac.id
}

\begin{abstract}
ABSTRAK
Demam berdarah adalah suatu penyakit yang disebabkan oleh virus dengue. Virus dengue ini akibat dari gigitan nyamuk Aedes Aegypty. Nyamuk Aedes Aegypti ini merupakan jenis serangga (insecta) dari ordo diptera yang dapat mengakibatkan kematian kepada manusia yang terkena gigitannya.Penelitian ini bertujuan untuk mengetahui perilaku masyarakat dalam pencegahan demam berdarah di RT $03 R W 03$ Kelurahan Tangkerang Tengah Kecamatan Marpoyan Damai Pekanbaru. Metode Penelitian ini menggunakan jenis penelitian deskriptif, sampel diambil dengan menggunakan simple Total sampling dengan jumlah 66 sampel. Hasil penelitian yang dilakukan pada tanggal 13 s/d 16 Februari 2015 menunjukkan mayoritas perilaku masyarakat dalam pencegahan demam berdarah Di RT 03 RW 03 Kelurahan Tangkerang tengah Kecamatan Marpoyan Damai Pekanbaru adalah dalam kategori Baik sebanyak 38 Responden (57,6\%) dan kategori tidak baik sebanyak 28 Responden (42,4\%). Sedangkan Perilaku Responden berdasarkan Observasi yaitu kategori Baik sebanyak 47 Responden $(71,2 \%)$ dan kategori tidak baik sebanyak 19 (28,8 \%). Diharapkan masyarakat untuk dapat meningkatkan pengetahuan tentang pencegahan demam berdarah bagi kesehatan.
\end{abstract}

Kata Kunci : Pengetahuan, Masyarakat, Dalam Pencegahan Demam Berdarah

\section{PENDAHULUAN}

Pencegahan berkembangnya nyamuk Aedes aegypti sebagai penular DBD menjadi mutlak dilakukan karena vaksin yang efektif terhadap DBD sampai saat ini belum tersedia. Pengobatan yang dilakukan hanya untuk mengurangi gejala sakit dan mengurangi risiko kematian. Penanggulangan DBD secara umum ditujukan kepada pemberantasan rantai penularan dengan memusnahkan pembawa virusnya (vektor) yaitu nyamuk Aedes aegypti, dengan memberantas sarang perkembangbiakannya yang umumnya ada di air bersih tempat penampungan air (Soedarmo, 2005).

Mengingat tempat hidup (habitat) nyamuk Aedes aegypti adalah pada tempat-tempat yang terdapat air bersih, maka orang yang menjaga kebersihan lingkungan masih mungkin terkena DBD. Oleh karena itu program pemberantasan DBD tidak cukup hanya dengan menjaga kebersihan lingkungan, tetapi harus menghindari keberadaan jentik di tempat air yang bersih, misalnya menguras bak mandi setiap 1 minggu sekali. Hal ini dilakukan mengingat/kehidupan nyamuk Aedes aegypti diketahui siklus hidupnya selama bertelur hingga menetas 10 sampai 14 hari. Dengan menguras bak mandi 1 minggu sekali tidak memberi kesempatan Aedes aegypti untuk bertelur sehingga dapat menghilangkan tempat perindukannya. (Notoadjho, 2007).

Menurut WHO antara tahun 1975-1996 DBD terdeteksi keberadaannya di wilayah Amerika, Eropa Selatan, Afrika Utara, Afrika Selatan, Afrika Utara, Mediterania Timur, Australia dan pada beberapa pulau di Samudra 
India, Pasifik Selatan dan Tengah serta Karibia. (WHO, 1999).

Tetapi sekarang daerah endemic DBD banyak terdapat di Asia (Thailand, Filipina, Kamboja, Malaysia, Singapura, Cina), karena musim epidemik terjadi disaat musim hujan yang hampir setiap tahun terjadi. Epidemik artinya keadaan dimana suatu masalah kesehatan (umumnya penyakit) yang ditemukan pada suatu daerah tertentu dalam waktu yang singkat berada dalam frekuensi (jumlah) yang meningkat (Soegijanto, 2006).

Di Indonesia jumlah penderita penyakit demam berdarah atau insidennya meningkat dan menyebar/ke seluruh Propinsi di Indonesia. Peningkatan kasus DBD terjadi sejak Nopember 2003 di beberapa daerah. Pada akhir Mei 2004, jumlah kasus DBD dilaporkan 59.321 kasus dengan jumlah kematian 669 kasus. Angka kematian atau Case Fatality Rate (CFR) selama periode KLB tahun 2004 sebesar 1,1 persen. Sedangkan lima tahun sebelumnya yaitu pada tahun 1998 CFR sebesar 1,8 persen. Sedangkan tahun 2013 ini, selama Januari-Juni DBD dilaporkan terjadi di 31 provinsi dengan jumlah kasus sebanyak 48.905 penderita, dan 376 diantaranya meninggal dunia. Provinsi yang dilaporkan KLB DBD tahun 2013 yaitu Lampung,Sulsel, Kalteng, dan Papua.

Di Propinsi Sumatera Utara kasus DBD tiap tahun terjadi. Data tahun 2003-2007 menunjukkan bahwa IR (Incidence Rate) 7,9230,75 per 100.000 penduduk dan CFR (Case Fatality Rate) 0,91\%-2,44\%. Selama kurun waktu lima tahun tersebut terdapat beberapa Kabupaten/Kota (Medan, Deli Serdang, Binjai, Tebing Tinggi, Pematang Siantar, Simalungun) yang dinyatakan daerah endemis DBD di mana kabupaten/kota tersebut merupakan wilayah yang dalam 3 tahun terakhir, setiap tahun ada penderita DBD (Dinas Kesehatan Propinsi Sumatera Utara, 2008).
Dinas Kesehatan Provinsi Riau Bidang Pencegahan, pengendalian Penyakit dan Penyehatan Lingkungan menyatakan penyakit DBD kian mengancam dan bepotensi menjangkiti sejumlah kalangan warga di sana, mengingat musim hujan yang masih terus mendera. Jumlah kasusnya memang belum begitu signifikan, namun telah mengakibatkan 17 kematian $(1,97) \%$ dari 862 kasus dan hal ini harus diwaspadai. Kasus tersebut terjadi di wilayah kabupaten dan kota di Riau sejak januari hingga Oktober 2012.

Tanggal 6 Desember 2011, Walikota Pekanbaru menetapkan kejadian Luar Biasa (KLB) untuk Demam Berdarah Dengue (DBD), karena kasus DBD sudah mencapai 406 kasus. Jumlah tersebut sudah lebih dari dua kali lipat dari tahun 2010 lalu yaitu 202 kasus. Jadi sesuai Permenkes Nomor 1501/Menkes/Per/IX/2010 tentang kategori KLB DBD, maka Pekanbaru telah ditetapkan KLB DBD. Kasus DBD di Kecematan Marpoyan Damai merupakan jumlah kasus tertinggi dengan 63 kasus.

Sementara jumlah korban meninggal akibat DBD mencapai 6 orang. Jumlah tersebut meningkat bila dibanding pada 2010 lalu yaitu hanya satu orang. Daerah yang memiliki kasus tertinggi kedua di Kecamatan Payung Sekaki dengan 58 kasus dan menyusul Kecamatan Tampan dengan 53 kasus. Secara rinci, di Kecamatan Sukajadi terdapat 33 kasus, di Kecamatan Senapelan 23 kasus, di Kecamatan Pekanbaru Kota 19 kasus, di Kecamatan Rumbai Pesisir 39 kasus, di Kecamatan Rumbai 21 kasus, di Kecamatan Limapuluh 27 kasus, di Kecamatan Sail 15 kasus, di Kecamatan Bukit Raya 30 kasus, dan di Kecamatan Tenayan Raya 25 kasus. Kecamatan Bukit Raya 30 kasus, dan di Kecamatan Tenayan Raya 25 kasus. Kemudian pada tahun 2013 di Kota Pekanbaru terdapat 118 kasus dengan satu kematian, $(0,85)$ 
kemudian Kabupaten Kampar 128 kasus dengan tiga kematian $(2,34) \%$.

Berdasarkan Observasi yang di lakukan pada beberapa rumah warga di Kelurahan Tangkerang Tengah Kecamatan Marpoyan Damai pada tanggal 24 januari 2014, terlihat adanya genangan air di beberapa kaleng bekas dan terdapat jentik-jentik nyamuk yang berpotensi untuk perkembang biakan nyamuk Aedes Aegipty, oleh karena tersebut, maka peneliti tertarik untuk melakukan penelitian mengenai perilaku masyarakat dalam pencegahan Demam Berdarah Dengue (DBD) di RT 03/RW/03 Kelurahan Tangkerang Tengah Kecamatan Marpoyan Damai Pekanbaru.

\section{METODE PENELITIAN}

Penelitian menggunakan metode penulisan deskriptif, yaitu suatu metode penelitian yang dilakukan dengan tujuan utama untuk membuat gambaran atau deskripsi tentang suatu keadaan secara objektif. Penelitian ini dilakukan dengan menempu langkah-langkah pengumpulan data, klasifikasi, pengolahan data, membuat kesimpulan dan laporan (Notoatmodjo, 2005).

Sampel dalam penelitian ini yaitu sebagian dari masyarakat Kelurahan Tangkerang Tengah Kecamatan Marpoyan Damai Pekanbaru dengan teknik pengambilan sampel yaitu metode " Total Sampling ", dimana peneliti dengan sengaja mengambil di RT 03 RW 03 Kelurahan Tangkerang Tengah kecematan Marpoyan Damai Pekanbaru sebanyak 66 KK (responden),

Dalam analisa data peneliti menggunakan analisa univariate, yaitu analisis yang dilakukan terhadap tiap variabel dari hasil penelitian yang hanya menggunakan hasil perhitungan terhadap tiap variabel dari hasil penelitian tiap variabel. Hasil penelitian yang nanti akan digunakan sebagai bahan pengembangan keputusan dalam penanggulangan untuk pembahasan dan kesimpulan.

Menurut Sudijono (2009), dengan melihat persentase data yang dikumpulkan dan sajian dalam bentuk tabel frekuensi dan dipersentasikan dari tiap variabel Hasil perhitungan persentase tersebut dihitung nilai median (nilai tengah) dengan menggunakan kampotensasi kemudian dikelompokkan dalam dua kategori, yaitu: perilaku Baik (> nilai median) dan perilaku tidak baik $(<$ nilai median).

\section{TINJAUAN TEORITIS}

\section{Demam Berdarah}

Demam Berdarah Dengue adalah suatu penyakit menular yang disebabkan oleh virus Dengue dan ditularkan oleh nyamuk Aedes aegypti yang ditandai dengan demam mendadak dua sampai tujuh hari tanpa penyebab yang jelas,lemah atau lesu, gelisah, nyeri ulu hati, disertai dengan tanda-tanda perdarahan di kulit berupa bintik perdarahan (petechia), ruam (purpura). Kadang-kadang mimisan, berak darah, muntah darah, kesadaran menurun dan bertendensi menimbulkan renjatan (syok) dan kematian (Mubin, 2005).

\section{Pencegahan Penyakit Demam berdarah}

Pencegahan dilakukan dengan menghindari gigitan nyamuk diwaktu pagi sampai sore, karena nyamuk aedes aktif di siang hari (bukan malam hari). Misalnya hindarkan berada di lokasi yang banyak nyamuknya di siang hari, terutama di daerah yang ada penderita DBD nya.

Beberapa metode yang dapat di lakukan untuk pencegahan Demam Berdarah antara lain :

\section{a. Metode Lingkungan}


Pengendalian nyamuk Aedes aegypti dengan metode berbasis lingkungan dilakukan dengan pemberantasan sarang nyamuk. Nyamuk Aedes aegypti biasanya hidup dan berkembang biak pada genangan air bersih. Untuk itu, kita harus mewaspadai dan rajin memantau tempat yang berpotensi menjadi tempat berkembangbiakan nyamuk tersebut. Beberapa hal yang dapat di lakukan untuk membasmi sarang nyamuk antara lain:

1.) Menguras bak mandi atau tempat penampungan air sekurang-kurangnya seminggu sekali.

2.) Menganti atau menguras vas bunga dan tempat minum burung paling tidak seminggu sekali.

3.) Menutup rapat-rapat tempat penampungan air.

4.) Mengubur kaleng-kaleng bekas, wadah plastik, dan barang-barang lain yang dapat menampung air hujan.

\section{b. Metode Biologis}

Dalam bidang pertanian, kita sering mendengar istilah pengendalian hama secara biologis, yakni pengendalian atau pemusnahan hama menggunakan predator atau musuh alaminya. Dengan prinsip yang sama, kita dapat menggunakan cara biologis untuk pengendalian perkembangbiakan nyamuk Aedes aegypti caranya, dengan mengunakan ikan pemakan jentik nyamuk (misalnya ikan adu atau cupang) dan bakteri jenis Bt. H-14.

\section{c. Metode Kimiawi}

Pengendalian secara kimiawi dilakukan dengan mengunakan bahan-bahan kimia yang dapat membunuh nyamuk scara kimiawi adalah sebagai berikut.

\section{a. Pengasapan ( fogging )}

Untuk mengurang

kemungkinan

penularan Demam Berdarah sampai batas tertentu, kita dapat melakukan pengasapan pada tempat-tempat yang menjadi sarang nyamuk Aedes aegypti.dengan cara ini, nyamuk-nyamuk dewasa penularan virus
Dengue bias di basmi. Bahan kimia yang biasa digunakan dalam proses pengasapan adalah malathion dan fetion.

\section{d. Pemberian bubuk abate (temephos)}

Dengan menambahkan bubuk abate pada tempat-tempat penampungan air, seperti kolam, tempayan, vas bunga, dan sebaiknya dapat membunuh jentik-jentik nyamuk yang ada di dalamnya. Kita tidak perlu khawatir dengan kualitas air yang telah di beri bubuk abate, karena bahan kimia ini tidak membahayakan kesehatan manusia.

\section{HASIL DAN PEMBAHASAN}

Berdasarkan hasil penelitian yang dilakukan peneliti pada tanggal $13 \mathrm{~s} / \mathrm{d} 16 \mathrm{Mei}$ 2015 di RT 03 RW 03 Kelurahan Tangkerang Tengah Kecamatan Marpoyan Damai Pekanbaru terhadap 66 responden dengan menggunakan alat ukur kuesioner untuk mengetahui perilaku masyarakat dalam pencegahan demam berdarah didapatkan data sebagai berikut:

\section{Tabel 1 Distribusi Frekuensi Umur Responden}

\begin{tabular}{|c|c|c|c|}
\hline No & Umur & Frekuensi & Persentase \\
\hline 1 & Remaja Akhir (17-25) & 23 & $30.30 \%$ \\
\hline 2 & Dewasa Awal (26-35) & 24 & $36.36 \%$ \\
\hline 3 & Dewasa Akhir (36-35) & 9 & $19.69 \%$ \\
\hline 4 & Lansia Awal (46-55) & 7 & $10.60 \%$ \\
\hline \multirow[t]{2}{*}{5} & Lansia Akhir (56-65) & 3 & \\
\hline & Jumlah & 66 & $100 \%$ \\
\hline
\end{tabular}

Tabel 2 Distribusi Frekuensi Jenis Kelamin Responden

\begin{tabular}{clcl}
\hline No & Jenis kelamin & Frekuensi & Persentase \\
\hline $\mathbf{1}$ & Laki-Laki & 27 & $40.90 \%$ \\
$\mathbf{2}$ & Perempuan & 39 & $59.09 \%$ \\
\hline & Jumlah & $\mathbf{6 6}$ & $\mathbf{1 0 0 \%}$ \\
\hline
\end{tabular}

Tabel 3 Distribusi Frekuensi Tingkat Pendidikan Responden

\begin{tabular}{|clcc}
\hline No & $\begin{array}{c}\text { Tingkat } \\
\text { Pendidikan }\end{array}$ & Frekuensi & Persentase \\
\hline $\mathbf{1}$ & $\begin{array}{l}\text { Rendah (SD dan } \\
\text { SMP) }\end{array}$ & 28 & $42,42 \%$ \\
$\mathbf{2}$ & $\begin{array}{l}\text { Menengah } \\
\text { (SLTA/Sederajat) }\end{array}$ & 34 & $51,52 \%$ \\
\end{tabular}




\begin{tabular}{ccrr}
3 & Tinggi (DIII \& SI) & 4 & $6,06 \%$ \\
\hline & Jumlah & $\mathbf{6 6}$ & $\mathbf{1 0 0 \%}$ \\
\hline
\end{tabular}

Tabel 4 Distribusi Frekuensi Pekerjaan Responden

\begin{tabular}{clcc}
\hline No & Pekerjaan & Frekuensi & Persentase \\
\hline 1 & PNS & 4 & $6.06 \%$ \\
\hline 2 & Wiraswasta & 19 & $28.78 \%$ \\
\hline 3 & Swasta & 13 & $19.69 \%$ \\
\hline 4 & IRT & 26 & $39.39 \%$ \\
\hline 5 & Mahasiswa & 2 & $3.03 \%$ \\
\hline 6 & Buruh & 2 & $3.03 \%$ \\
\hline & Jumlah & $\mathbf{6 6}$ & $\mathbf{1 0 0 \%}$ \\
\hline
\end{tabular}

Tabel 5 Distribusi Frekuensi Berdasarkan Informasi Yang Diterima Tentang Pencegahan DBD

\begin{tabular}{clcc}
\hline No & Informasi & Frekuensi & Persentase \\
\hline $\mathbf{1}$ & Ya & 60 & $90.90 \%$ \\
\hline $\mathbf{2}$ & Tidak & 6 & $9.09 \%$ \\
\hline & Jumlah & $\mathbf{6 6}$ & $\mathbf{1 0 0 \%}$ \\
\hline
\end{tabular}

Tabel 6 Distribusi Frekuensi Perilaku Responden Dalam Pencegahan DBD berdasarkan Kuesioner

\begin{tabular}{llll}
\hline No & Perilaku & F & \% \\
\hline 1 & Baik & 38 & 57,6 \\
\hline 2 & Tidak baik & 28 & 42,4 \\
\hline & Jumlah & $\mathbf{6 6}$ & $\mathbf{1 0 0 , 0}$ \\
\hline
\end{tabular}

Tabel 7 Distribusi Frekuensi Perilaku Responden Dalam Pencegahan DBD berdasarkan Observasi

\begin{tabular}{clcc}
\hline No & Perilaku & F & \% \\
\hline 1 & Baik & 47 & 71,2 \\
\hline 2 & Tidak baik & 19 & 28,8 \\
\hline & Jumlah & $\mathbf{6 6}$ & $\mathbf{1 0 0 , 0}$ \\
\hline
\end{tabular}

Perilaku Baik Responden dalam Pencegahan DBD dapat digambarkan pada beberapa hal sebagai berikut:

1. Berdasarkan kuesioner bahwa 47 responden $(71,2 \%)$ yang memiliki bak mandi secara keseluruhan (100\%) menguras bak mandi setiap minggu, $5(7,6 \%)$ responden yang memiliki vas bunga secara keseluruhan (100\%) mengganti air vas bunga setiap minggu, 14 responden $(21,2 \%)$ yang memiliki wadah air minum hewan peliharaan secara keseluruhan (100\%) diganti setiap minggu, 33 Responden (60\%) yang menampung air di ember secara keseluruhan (100\%) dalam keadaan tertutup, $42(63,6 \%)$ responden yang memiliki kaleng bekas yang dapat menampung air hujan di halaman rumahnya secara keseluruhan (100\%) menanganinya dengan cara dikubur,

2. Berdasarkan kuesioner 49 Responden (74,2\%) yang memiliki wadah plastik bekas yang dapat menampung air hujan secara keseluruhan $(100 \%)$ di halaman rumahnya secara keseluruhan $(100 \%)$ menanganinya dengan cara dikubur, 34 responden $(51,5 \%)$ yang memiliki tanki air secara keeluruhan $(100 \%)$ dalam keadaan tertutup, 60 Responden $(90,9 \%)$ yang memiliki ban bekas yang dapat menampung air hujan di halaman rumahnya secara keseluruhan $(100 \%)$ menanganinya dengan cara dikubur, dan 32 responden $(48,5 \%)$ terdapat parit yang tergenang air hujan di halaman rumahnya secara keseluruhan (100\%) menyatakan tidak terdapat jentik nyamuk.

3. Berdasarkan Observasi sebanyak 37 Responden (56,1\%) tidak ditemukan kaleng/ ban bekas di halaman rumahnya, 62 responden $(93,9 \%)$ tidak ditemukan wadah plastik yang dapat menampung air hujan, 57 responden $(86,4 \%)$ tidak memiliki vas bunga yang berisi air, 34 responden $(51,5 \%)$ yang memiliki tanki air secara keseluruhan $(100 \%)$ dalam keadaan tertutup rapat.

4. Berdasarkan Observasi tidak ditemukan Jentik nyamuk pada Kaleng bekas yang menampung air hujan sebanyak 51 responden $(77,3 \%)$, pada wadah plastik bekas yang menampung air hujan sebanyak 62 responden $(93,9 \%)$, dan pada ember penampung air secara keseluruhan (66 
responden/100\%) tidak ditemukan jentik nyamuk.

Perilaku Baik responden tersebut dipengaruhi oleh Informasi yang didapat oleh responden tentang Pencegahan DBD, dari hasil penelitian bahwa mayoritas responden pernah mengenal informasi tentang pencegahan demam berdarah yaitu sebanyak $60(90,90 \%)$ responden.

Menurut Yudes (2011), semakin banyak seseorang mencari dan menemukan informasi, maka orang tersebut tidak akan ketinggalan dalam berbagai informasi, bahkan sebaliknya jika seseorang sedikit kemauannya untuk mencari dan menemukan informasi kemungkinan besar seseorang akan ketinggalan informasi baik mengenai hal umum, kesehatan maupun lainnya.

Menurut asumsi peneliti, faktor yang mempengaruhi pengetahuan responden adalah informasi yang didapatkan. Semakin banyak informasi yang didapatkan seseorang maka semakin tinggi pula pengetahuannya.

Selanjutnya harus diperhatikan pula bahwa masih ada responden yang berperilaku tidak baik dalam pencegahan DBD, hal tersebut dapat digambarkan sebagai berikut:

1. Kesadaran dalam memberikan Bubuk Abate pada tempat penampungan air; dari 66 responden hanya 21 responden $(31,82 \%)$ yang menggunakan bubuk abate, dan yang tepat waktu dalam pemberiannya (1-3 bulan) sekitar 9 responden $(13,64 \%)$

Hal tersebut didukung oleh peneliti Yunita (2007), menyebutkan bahwa risiko keberadaan jentik Aedes aegypti pada rumah yang tidak diberi bubuk abate pada tempat penampungan airnya adalah sebesar 9,143 kali dibandingkan dengan rumah yang diberi abate pada tempat penampungan airnya terhadap kejadian DBD.Menurut asumsi peneliti, faktor yang mempengaruhi responden adalah kurangnya pengetahuan masyarakat dalam pemberian bubuk abate pada tempat-tempat tergenangnya air.

2. Berdasarkan Observasi Lingkungan Fisik rumah responden; sebanyak 29 responden (43.9\%) dihalaman rumahnya terdapat kaleng/ban bekas yang menampung air hujan, 34 responden $(51,5 \%)$ di halaman rumahnya terdapat tumpukan sampah yang menampung air hujan, dan 60 responden (90.0\%) di dalam rumahnya terdapat pakaian yang tergantung dan menumpuk.

Hal tersebut didukung oleh peneliti minsarnawati (2015), menyebutkan bahwa faktor resiko dari dbd yaitu lingkungan, perilaku, pelayanan kesehatan dan herediter ,dari lingkungan karena geografis di indonesia masih iklim tropis dan curah hujan tinggi. Menurut asumsi peneliti, faktor yang mempengaruhi responden yaitu kurangnya pengetahuan masyarakat dalam kebersihan lingkungan sekitar rumah, karna masih terdapatnya kaleng/ban bekas yang menampung air hujan.

3. Berdasarkan Observasi di lingkungan Rumah; Responden yang memiliki genangan air di parit sekitar rumah yaitu sebanyak 49 responden $(74.2 \%)$, yang mana pada parit tersebut terdapat jentik nyamuk sebanyak $43(65,2 \%)$ responden yang menunjukkan perilaku tidak baik dalam pencegahan DBD.

Hal tersebut didukung oleh penelitia Teguh Waluyo (2001), di Desa Pagelak Banjar negara menunjukkan bahwa proporsi rumah yang ada parit/selokan mempunyai kecenderungan untuk terjadinya penyakit demam berdarah. Hal ini disebabkan saluran air yang digunakan untuk pembuangan air hujan, limbah rumah tangga menggenang dan dapat digunakan sebagai tempat berkembang biak nyamuk. Menurut asumsi peneliti, faktor yang mempengaruhi responden adalah kurang nya informasi dan pengetahuan masyarakat tentang pencegahan penyakit demam berdarah.

4. Berdasarkan Observasi bahwa mayoritas pada halaman rumah responden terdapat 
wadah plastik bekas yang menampung air hujan (perilaku tidak baik) yaitu sebanyak 49 responden $(74,2 \%)$, yang mana sebanyak $4(6,1 \%)$ wadah plastik tersebut ditemukan jentik nyamuk.

Hal tersebut didukung oleh peneliti yulina, (2000) perilaku yang sering kali terkait dengan lingkungan misalnya kebiasaan memuang sampah yang bisa menampung air hujan semacam plastik, kaleng dan botol ,lalu tidur di waktu -waktu saat vektor mengigit sekitar jam 8-10 pagi dan sekitar jam 4-6 sore. Kesadaran dan pengetahuan yang masih kurang. Menurut asumi peneliti, faktor yang mempengaru responden berpilaku tidak baik yaitu kurangnya kesadar dan pengetahuan masyarakat dalam perilaku pencegahan penyakit demam berdarah.

5. Berdasarkan observasi jentik nyamuk (perilaku tidak baik) di lingkungan rumah responden; sebanyak 43 (65.2\%) ditemukan di parit, sebanyak $15(22,7 \%)$ ditemukan pada kaleng bekas yang menampung air hujan, dan sebanyak 4 $(6,1 \%)$ ditemukan pada wadah plastik yang menampung air hujan.

Hal ini didukung oleh peneliti Hadinegoro (2001), semakin mudah nyamuk Aedes menularkan virusnya dari satu orang ke orang lainnya karena pertumbuhan penduduk yang tinggi dapat meningkatkan kesempatan penyakit DBD menyebar, urbanisasi yang tidak terencana dan tidak terkendali, tidak adanya kontrol vektor nyamuk yang efektif di daerah endemis, peningkatan sarana transportasi. Menurut asumsi peneliti, faktor mempengaruhi responden adalah kurang nya pengetahuan masyarakat tentang cara memberantas jentik nyamuk.

\section{KESIMPULAN DAN SARAN}

Berdasarkan hasil penelitian yang dilakukan di RT 03 RW 03 Kelurahan Tangkerang Tengah Kecamatan Marpoyan Damai Pekanbaru pada tanggal 13-16 Mei 2015 terhadap 66 responden, bahwa Perilaku
Responden dalam Pencegahan DBD secara umum berdasarkan Kuesioner yaitu kategori Baik sebanyak 38 Responden (57,6\%) dan kategori tidak baik sebanyak 28 Responden $(42,4 \%)$. Sedangkan Perilaku Responden berdasarkan Observasi yaitu kategori Baik sebanyak 47 Responden $(71,2 \%)$ dan kategori tidak baik sebanyak 19 Responden $(28,8 \%)$.

Jadi dapat disimpulkan bahwa responden sebagian besar berperilaku Baik dalam Pencegahan DBD baik berdasarkan kuesioner maupun observasi.

\section{DAFTAR PUSTAKA}

Azwar S, (2005). Sikap Manusia teori dan Pengukurannya, Pustaka Pelajar, Yogyakarta.

Chin James, (2000). Manual Pemberantasan Penyakit Menular (Terjemahan I. Nyoman Kandun), Edisi 17, Cetakan II tahun 2006.

Dinkes Kota Pekanbaru, (2007). Profil Kesehatan Kota Pekanbaru.Depkes R.I, 1992. Petunjuk Tehnisi pengamatan Penyakit Demam Berdarah Dengue.

Dinas Kota Pekanbaru, (2005). Pencegahan dan Pemberantasan Demam Berdarah Dengue di Indonesia,Ditjen PPM \& PL, Jakarta.

Dinas Kota Pekanbaru, (2005). Penyelidikan Epidemiologis, Penanggulangan Fokus dan Penanggulangan Vektor Pada Kejadian Luar Biasa Demam Berdarah Dengue di Indonesia,Ditjen PPM \& PL, Jakarta.

Dinas Kota Pekanbaru, (2006). Pemberantasan Nyamuk Penular Demam Berdarah Dengue di Indonesia,Ditjen PPM \& PL, Jakarta.

Hadinegoro, R.S, dkk, Tata Laksana Demam Berdarah Dengue di Indonesia. 
Rineka Cipta Riduwan, (2005). Promosi Kesehatan dan Ilmu Perilaku dan Skala Pengukuran Variabel-variabel Penelitian, Cetakan Ketiga, Januari 2005.

Soegijanto, S, (2001). Membentuk Pola Perilaku Manuasia Pembangunan, IPB Press, Bogor.

Koban, Antonius Wiwan, (2005). Kebijakan Pemberantasan Wabah Penyakit; KLB Demam Berdarah Dengue

Soedarmo SSP, (2005). Demam Berdarah (Dengue) pada Anak. Penerbit UI . Press. Jakarta.

Soegijanto S, (2006). Demam Berdarah Dengue. Edisi 2. Airlangga University Press.

Surabaya.

Yudes (2011), perilaku pemberantasan demam berdarah. Jurnal kesehatan lingkungan perkarangan rumah
Yunita K.R. (2007), Perilaku 3M, Abatisasi dan Keberadaan Jentik Aedes Hubungannya dengan Kejadian Demam Berdarah Dengue.Jurnal Kesehatan Lingkungan

Tegu waluyono.( 2005). Informasi Penyakit Menular Demam Berdarah. Jurnal kesehatan

Yulina (2001) Membina Gerakan Pemberantasan Sarang Nyamuk Demam Berdarah Dengue (PSN)DBD) : Petunjuk Bagi Kelompok Kerja Operasional Pemberantasan Penyakit Demam Berdarah Dengue (DBD). Jakarta: Ditjen Pemberantasan Penyakit Menular dan Penyehatan Lingkungan Pemukiman.

Yudesi (2011), pemberatasan jentik nyamuk di perkarangan rumah. Jurnal pencegahan penyakit demam berdarah 